\title{
Ontogenetic and tissue-specific expression of preproghrelin in the Atlantic halibut, Hippoglossus hippoglossus L.
}

\author{
Anthony J Manning, Harry M Murray, Jeffrey W Gallant, Makoto P Matsuoka, Emily Radford \\ and Susan E Douglas
}

Institute for Marine Biosciences, 1411 Oxford Street, Halifax, Nova Scotia, B3H $3 Z 1$ Canada

(Correspondence should be addressed to A J Manning; Email: amanning@munalum.ca)

\begin{abstract}
Ghrelin is a conserved vertebrate hormone that affects both $\mathrm{GH}$ release and appetite. We have cloned and characterized Atlantic halibut preproghrelin cDNA and examined for the first time preproghrelin expression during fish larval development using quantitative real-time PCR. In addition, cellular sites of expression in larvae and tissue-specific expression in 3-year-old halibut were studied. A full-length cDNA for preproghrelin was isolated from halibut stomach tissue. The $899 \mathrm{bp}$ cDNA encodes an open reading frame of 105 amino acids that is comprised of a signal peptide and two peptides with high similarity to ghrelin and obestatin. The deduced amino acid sequence of halibut ghrelin peptide (GSSFLSPSHKPPKGKPPRA) shows significant conservation relative to other teleostean sequences and is identical to human ghrelin for the first seven amino acids of the sequence. The putative obestatin peptide is well-conserved among fishes
\end{abstract}

but shares limited similarity with its human counterpart. Expression of ghrelin was localized to two different cell types in the stomach of larval halibut by in situ hybridization. However, sensitive PCR assays on tissues collected from 3 -year-old fish additionally identified ghrelin transcripts in pyloric caecae, intestine, and in immature ovary and testis. Ontogenetic studies detected ghrelin expression prior to exogenous feeding during larval development (hatching and mouth-opening stages) with increased expression occurring through metamorphosis. This increase was pronounced during climax metamorphosis and coincided with stomach differentiation. Patterns of preproghrelin expression suggest that ghrelin has important roles during and after larval development in halibut, and that ghrelin is associated with digestive and gonadal tissues in this teleost.

Journal of Endocrinology (2008) 196, 181-192

\section{Introduction}

Ghrelin has been shown to be a major endocrine regulator of appetite, energy balance, and growth hormone (GH) secretion (Kojima et al. 1999, Gualillo et al. 2006). This conserved peptide hormone has been identified among most vertebrate groups ranging from the teleost fishes to humans, and recent literature suggests that the structure, distribution, and physiological functions of ghrelin in fish and mammals are comparable (Unniappan \& Peter 2005). Mammalian ghrelin is consistently found in stomach and intestinal tissues, but is produced in a variety of other tissues as well including the hypothalamus, pituitary, pancreas, and reproductive tissues (van der Lely et al. 2004). Nevertheless, gastric production is the primary source of ghrelin in the blood (Barreiro \& Tena-Sempere 2004). Gastric ghrelin secretion increases in response to fasting and stimulates appetite through interactions with orexigenic neurons in the hypothalamus (Gualillo et al. 2006). The discovery of ghrelin was made, however, as a result of its role in GH release. Kojima et al. (1999) identified ghrelin as the only endogenous ligand yet to be found for the GH secretagogue receptor (GHS-R), which binds synthetic GHS such as MK-677 and GHRProtein-6 (van der Lely et al. 2004). The effect of ghrelin on GH secretion is comparable with or potentially more potent than the classical hypothalamic regulator, $\mathrm{GH}$-releasing hormone (Kojima et al. 1999, Gualillo et al. 2006). In addition to appetite and GH secretion, ghrelin has been implicated in other functions involving gastric acid secretion and motility, pancreatic activity and carbohydrate metabolism, prolactin secretion, cardiovascular actions, reproduction, fetal growth and development, as well as effects on apoptosis and cell proliferation (Barreiro \& Tena-Sempere 2004, van der Lely et al. 2004, Gualillo et al. 2006, Sato et al. 2006). Recently, evidence has been presented that implicates ghrelin as a signal of energy insufficiency that is able to modulate the endocrine axis regulating reproduction. This role is opposite to that of leptin, a hormone that signals somatic adiposity and acts as an appetite suppressant (Barreiro \& Tena-Sempere 2004).

Ghrelin undergoes post-translational modifications, often appearing in acylated and unacylated forms in the blood. The acylation occurs at the third residue of the 'active core' consisting of a Gly-Ser-Ser-Phe motif at the N-terminus of the mature peptide. An octanoylated form, often seen in 
mammals, is responsible for the GHS effects (Kojima et al. 1999). Unacylated ghrelin has no effect on GH secretion and thus had been considered biologically inactive. However, recent studies have shown otherwise, with unacylated peptide having actions that mitigate acylated ghrelin effects on insulin secretion (Broglio et al. 2004, Gualillo et al. 2006). A further complication to the understanding of ghrelin regulation is the discovery that another peptide with potentially opposing effects on appetite, obestatin, is encoded in the preproghrelin mRNA transcript (Zhang et al. 2005). This peptide slows gastric emptying activity, antagonizing the stimulatory action of ghrelin (Zhang et al. 2005). However, obestatin secretion does not respond to fasting, nor does it induce $\mathrm{GH}$ secretion (Zhang et al. 2005). An obestatin encoding sequence has been recently identified in black sea bream, Acanthopagrus schlegelii (Yeung et al. 2006).

The wide spectrum of ghrelin actions has prompted research into its physiological functions in different animal models including fishes. Ghrelin has thus far been identified in nine different teleosts, from anguilliforms to perciforms: Japanese eel, Anguilla japonica (Kaiya et al. 2003a), goldfish, Carassius auratus (Unniappan et al. 2002), zebrafish, Danio rerio (GenBank Acc. AM055940), channel catfish, Ictalurus punctatus (Kaiya et al. 2005), rainbow trout, Oncorhynchus mykiss (Kaiya et al. 2003b), two tilapia species, Oreochromis mossambicus (Kaiya et al. 2003c) and Oreochromis niloticus (Parhar et al. 2003), sea bass, Dicentrarchus labrax (GenBank Acc. DQ665912), and black sea bream (Yeung et al. 2006). The size of ghrelin peptides is variable among teleosts, and more than one preproghrelin transcript may occur within a species (e.g., rainbow trout, Kaiya et al. 2003b). Posttranslational modifications of teleostean ghrelin include acylation as in mammals, C-terminal amidation unique to teleosts, and glycine C-terminus extension as found in channel catfish (Kaiya et al. 2005, Unniappan \& Peter 2005). Depending on the species, ghrelin is expressed either exclusively in the stomach or is distributed in other tissues as well, namely, brain, gill, heart, intestine, kidney, or spleen (Unniappan \& Peter 2005; above studies).

Physiological roles common to both teleostean and mammalian ghrelins include: orexigenic actions (Unniappan et al. 2004, Riley et al. 2005); stimulation of GH transcription and release (Kaiya et al. 2003a,b,c, 2005, Parhar et al. 2003, Ran et al. 2004); and stimulation of prolactin secretion (Kaiya et al. 2003a,c). Increased ghrelin transcription and peptide secretion have been reported in goldfish under short- and long-term fasting conditions (Unniappan et al. 2004). However, a response to fasting was not seen in sexually mature Nile tilapia (Parhar et al. 2003). Regulation of ghrelin secretion beyond meal frequency is not clear for teleosts, but recent evidence has shown that $\mathrm{GH}$ can stimulate ghrelin expression in sea bream (Yeung et al. 2006). Positive feedback may occur between $\mathrm{GH}$ and ghrelin under certain physiological conditions in fish.

Here, we examine the expression of ghrelin in a large pleuronectid flatfish, the Atlantic halibut, Hippoglossus hippoglossus. Halibut larvae hatch in an altricial state and spend their early development in a yolk-sac larval stage during which time growth is dependent on endogenous reserves supplied during maternal oogenesis. Many organs are in a rudimentary state and develop functionality during the larval period. For instance, the mouth is not functional and a differentiated stomach is absent at hatching (Pittman et al. 1990, Murray et al. 2006). Major developmental stages during larval growth include the onset of exogenous feeding (first feeding) and metamorphosis from the larval to juvenile stage. Metamorphosis is a complex and highly energy-dependent process during which physiological relationships mature, and key events such as ossification, blood pigmentation, and skin pigmentation take place. Flatfish metamorphosis is particularly complex due to eye migration and changes in body orientation. Larvae of the same natal age can exhibit considerable size variation, possibly due to differential appetite, food intake, or GH secretion. In this study, we present the full cDNA sequence of preproghrelin and, for the first time in fishes, the ontogenetic pattern of ghrelin expression through larval development. In addition, tissue and cellular sites of expression are investigated, and associations between larval size/developmental stage and ghrelin expression level are examined. Ghrelin's role as a feeding inducer may be pertinent for the survival of altricial halibut larvae, particularly at first feeding, since energy reserves are limited following yolk-sac absorption.

\section{Materials and Methods}

\section{Cloning of halibut preproghrelin $c D N A$}

Adult halibut stomach tissue was homogenized using a Polytron (Kinematica AG, Luzern, Switzerland) and total RNA was extracted according to the protocol specified by the RNeasy Midi-tissue kit (Qiagen). Following DNase treatment (DNA-free kit, Ambion, Austin, TX, USA), $2 \mu \mathrm{g}$ total RNA were used for first-strand cDNA (fscDNA) synthesis using Retroscript (Ambion) and a $3^{\prime}$ universal primer (RT UP; Table 1). The resulting cDNA was extracted with phenol:chloroform extraction (1:1), precipitated with ethanol, and resuspended in $50 \mu \mathrm{H}_{2} \mathrm{O}$.

A highly conserved portion of the preproghrelin cDNA was amplified by PCR using $3 \mu \mathrm{l}$ fscDNA as template with degenerate primer $\mathrm{P} 1$ and $3^{\prime}$ universal nested primer (P2 UNR; Table 1). The primer P1 was based on the conserved GSSFLSP motif of vertebrate ghrelin peptides. Amplification conditions consisted of an initial $1 \mathrm{~min}$ denaturation at $94{ }^{\circ} \mathrm{C} ; 32$ cycles of $30 \mathrm{~s}$ at $94{ }^{\circ} \mathrm{C}, 30 \mathrm{~s}$ annealing at $55^{\circ} \mathrm{C}$, and $1 \mathrm{~min}$ extension at $72{ }^{\circ} \mathrm{C}$; and a final 2 min extension at $72{ }^{\circ} \mathrm{C}$. The PCR products were resolved on a $1.6 \%(\mathrm{w} / \mathrm{v})$ Omnipur PCR plus agarose gel (EMD Chemistry Inc., Gibbstown, NJ, USA). The largest band ( $800 \mathrm{bp}$ ) was excised and purified using GFX PCR DNA and Gel Band Purification Kit (GE Healthcare, Baie 
Table 1 Primers used to isolate and sequence halibut ghrelin

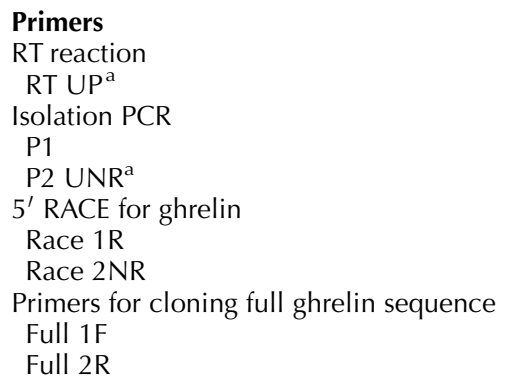

\begin{tabular}{|c|c|}
\hline $5^{\prime}$-TCG GAT CCC TCG AGA AGC $(\mathrm{T})_{18^{-} 3^{\prime}}$ & $62 \cdot 5$ \\
\hline $\begin{array}{l}\text { 5'-GGC TCC AGC TTC CTC AGC CC-3' } \\
5^{\prime} \text {-TCG GAT CCC TCG AGA AGC TT-3' }\end{array}$ & $\begin{array}{l}63 \cdot 1 \\
58 \cdot 8\end{array}$ \\
\hline $\begin{array}{l}5^{\prime} \text {-ATC TCT TGC AGC AAC ACG CC-3' } \\
5^{\prime} \text {-TCT GGT GTC ATG GTG ATG CC-3' }\end{array}$ & $\begin{array}{l}58 \cdot 6 \\
57 \cdot 4\end{array}$ \\
\hline $\begin{array}{l}5^{\prime} \text {-TTA ACA CTC TAT GTC CCT TCA TCA-3' } \\
5^{\prime} \text {-GTC AGT TGA TGC TTT ATT TTT ACC ACC-3' }\end{array}$ & \\
\hline
\end{tabular}

${ }^{a}$ RT universal primer and universal 3' nested primer (Tossi et al. 1997).

d'Urfé, QC, Canada), cloned using the TOPO TA cloning kit (pCR4-TOPO: $3956 \mathrm{bp}$; Invitrogen), and transformed into One Shot Chemically Competent Escherichia coli (Invitrogen). Plasmid DNA was isolated from positive recombinants using a QIAprep Miniprep Kit (Qiagen) and fully sequenced in both directions using the Templify kit and a Megabase sequencer (GE Healthcare).

The $5^{\prime}$ end of the cDNA was obtained by RACE using $1 \mu \mathrm{g}$ halibut stomach total RNA with primers Race $1 \mathrm{R}$ and Race 2NR (Table 1) and the SMART RACE cDNA Amplification Kit (BD Biosciences Clontech). RACE reactions were performed according to the manufacturer's recommendations using the following cycling conditions: $94^{\circ} \mathrm{C}$ for $5 \mathrm{~s} ; 5$ cycles of $94{ }^{\circ} \mathrm{C}$ for $5 \mathrm{~s}, 65^{\circ} \mathrm{C}$ for $10 \mathrm{~s} ; 72{ }^{\circ} \mathrm{C}$ for $1 \mathrm{~min} ; 25$ cycles of $94{ }^{\circ} \mathrm{C}$ for $5 \mathrm{~s}, 62^{\circ} \mathrm{C}$ for $10 \mathrm{~s}, 72{ }^{\circ} \mathrm{C}$ for $1 \mathrm{~min} ; 72^{\circ} \mathrm{C}$ for $10 \mathrm{~min}$. A nested PCR was performed using a 1/150 dilution of the primary reaction with primer Race $2 \mathrm{NR}$ and the same cycling conditions as the first reaction except that annealing temperatures of $62{ }^{\circ} \mathrm{C}$ and $60{ }^{\circ} \mathrm{C}$ were used. The $350 \mathrm{bp}$ PCR product was purified using a Montage kit (Millipore, Bedford, MA, USA) and sequenced directly. The full-length cDNA was amplified from fscDNA using primers Full $1 \mathrm{~F}$ and Full $2 \mathrm{R}$ (Table 1). PCR conditions were $94^{\circ} \mathrm{C}$ for $1 \mathrm{~min} ; 30$ cycles of $94{ }^{\circ} \mathrm{C}$ for $30 \mathrm{~s}, 53{ }^{\circ} \mathrm{C}$ for $30 \mathrm{~s}, 72^{\circ} \mathrm{C}$ for $90 \mathrm{~s}$; final extension at $72^{\circ} \mathrm{C}$ for $3 \mathrm{~min}$. The amplicon was purified, cloned, and sequenced as described above.

\section{Sampling of larval halibut}

Atlantic halibut gametes were obtained from captive broodstock and the larvae reared at Scotian Halibut Limited (Clark's Harbour, NS, Canada; $43^{\circ} 26 \cdot 3^{\prime} \mathrm{N} ; 65^{\circ}$ $\left.37 \cdot 8^{\prime} \mathrm{W}\right)$ according to standard industry protocols. Samples of larvae were collected at five developmental periods: hatching (S1), mouth opening (S2), postnotochord flexion/pro-metamorphosis (S6), active metamorphosis (S7-S9), and late metamorphosis/juvenile $(\mathrm{S} 9+)$ (Table 2). The size and morphology of the larvae in these collections were compared with published staging descriptions for Atlantic halibut (Pittman et al. 1990, Sæle et al. 2004). Additional samples of larvae from prometamorphic to early climax metamorphosis (S7-S9) were taken and graded according to size and developmental stage (Table 3). For this latter sample, visceral material was dissected from five individuals from each stage for investigation of ghrelin gene expression.

All larvae were killed with an overdose of tricaine methanesulfonate (TMS, $0 \cdot 1 \mathrm{~g} / 1$, Syndel Laboratories, Vancouver, BC, Canada) placed in RNAlater (Ambion) for up to $24 \mathrm{~h}$ at $4{ }^{\circ} \mathrm{C}$, removed from RNAlater, and stored at $-80^{\circ} \mathrm{C}$ until further processing. Notochord/standard length $(\mathrm{NL} / \mathrm{SL})$ and myotome height $(\mathrm{MH})$ measurements were performed post-preservation.

Table 2 Notochord length (NL), standard length (SL), myotome height $(\mathrm{MH})$, and developmental stage information for halibut larval collection samples 1 to 5 : individuals sampled for each collection are indicated $(n)$

NL or SL range $(\mathrm{mm}) \quad$ MH range $(\mathrm{mm})$

Collection

$1 n=20$

$2 n=20$

$3 n=15$

$4 n=5$

$5 n=5$
$19 \cdot 0-22 \cdot 0 \quad 5 \cdot 5-6 \cdot 5$

$28 \cdot 0-32 \cdot 0 \quad 7 \cdot 5-9 \cdot 0$

\section{Stage and description}

Stage 1: post-hatch, yolk-sac stage

Stage 2: mouth-opening, yolk-sac stage

Stage 6: prometamorphosis, post-notochord flexion

Stages 7-9: mixture of larvae in pro-, proclimax- and climax metamorphosis

Stage 9: advanced climax metamorphosis to post-metamorphic juvenile stage 
Table 3 Mean ( \pm s.D.) standard length (SL), myotome height $(\mathrm{MH})$, and developmental stage for groups of metamorphic larvae sampled for determination of visceral ghrelin expression in individuals

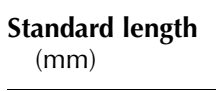

Group

$\begin{array}{ll}1 & 15 \cdot 9 \pm 2 \cdot 1 \\ 2 & 22 \cdot 4 \pm 0 \cdot 9\end{array}$

$3 \quad 25 \cdot 5 \pm 1 \cdot 0$

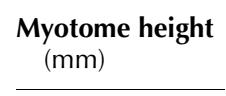

$3 \cdot 7 \pm 0 \cdot 5$

$6 \cdot 1 \pm 0 \cdot 3$

$7 \cdot 2 \pm 0 \cdot 4$

\section{Developmental stage}

7

8-9

9
Sampling of tissues from 3-year-old immature halibut

Halibut aged 3 years old (43-51 cm total length), originally reared at Scotian Halibut Limited, were sampled from juvenile populations held at the National Research Council Marine Research Station (Sandy Cove, NS, Canada; $44^{\circ}$ $\left.30 \cdot 4^{\prime} \mathrm{N} ; 63^{\circ} 36 \cdot 6^{\prime} \mathrm{W}\right)$. Three males and three females were given an overdose of TMS and then killed by post-cranial section of the spinal cord. Pieces of different tissues were dissected, placed directly in RNAlater (Ambion) for $16 \mathrm{~h}$ at $4{ }^{\circ} \mathrm{C}$, removed from RNAlater, and stored at $-80{ }^{\circ} \mathrm{C}$ until RNA isolation. Tissues examined include: gill, heart, liver, head kidney, body kidney, muscle, spleen, stomach, pyloric caecae/pancreas, intestine, gonad, as well as the pituitary and brain. Brain tissue was further dissected into five areas: olfactory bulb and telencephalon, optic lobe, thalamus and hypothalamus, cerebellum, and medulla oblongata.

\section{RNA extraction of larval and tissue samples from 3-year-old halibut}

Total RNA preparations used to investigate ghrelin expression through larval development were based upon extractions of pools of whole larvae. For early stages, 15 or 20 larvae were collected, whereas for later stages only five larvae were collected (Table 2). RNA was prepared from three replicate pools per stage. In an additional study, 15 individual larvae sampled during active metamorphosis (S7-S9) were divided among three size/developmental groups $(n=5$ larvae per group; Table 3). The viscera were dissected from each individual and total RNA extracted for each larva. Further investigation of visceral ghrelin expression was analyzed based on these separate extracts.

Whole larvae pools or individual viscera samples were weighed, placed in the recommended proportions of Trizol reagent (Invitrogen), and homogenized using a Polytron (Kinematica AG). Total RNA was extracted using Trizol in combination with Eppendorf Phase Lock Gel Heavy tubes (Brinkman, Mississauga, ON, Canada) as specified by the manufacturers' protocols. Following precipitation, RNA pellets were washed twice with $75 \%(\mathrm{v} / \mathrm{v})$ ethanol prior to resuspension in DEPC-treated water. RNA was quantified using a NanoDrop ND-1000 spectrophotometer (NanoDrop Technologies Inc., Wilmington, DE, USA) and $10 \mu \mathrm{g}$ aliquots were treated with DNAse I using DNA-free (Ambion). Samples were requantified before storage at $-80^{\circ} \mathrm{C}$.

An alternate extraction method was employed for tissues sampled from the six 3-year-old halibut. RNeasy Mini- or Midi-kits (Qiagen) were used following hand homogenization of tissue in RNeasy kit RLT buffer. Homogenates were passed through 18- then 21-gauge needles to disrupt tissue thoroughly. Eluted RNA isolates were treated with DNAfree (Ambion). Each individual was represented by its own tissue-based series of total RNA extracts that were processed separately in subsequent analyses.

Localization of ghrelin expression in larvae by in situ hybridization (ISH)

Probes for halibut ghrelin were prepared by in vitro transcription of the linearized full-length cDNA clone using the DIG RNA labeling kit (Roche Diagnostics) with modifications previously described in Murray et al. (2003).

Halibut sampled from larval pro-metamorphosis to postmetamorphic juvenile stages were killed with an overdose of TMS, fixed overnight at $4{ }^{\circ} \mathrm{C}$ by immersion in $4 \%(\mathrm{v} / \mathrm{v})$ paraformaldehyde in Tris- $\mathrm{HCl}(\mathrm{pH} 7 \cdot 8$ ), and processed for paraffin embedding (Murray et al. 2006). For larger fish, the visceral region and the head were removed and processed into paraffin separately.

Sections $(7 \mu \mathrm{m})$ were cut on a rotary microtome, placed on 3-aminopropyl-triethoxysilane-coated slides (Sigma) and baked overnight at $60{ }^{\circ} \mathrm{C}$. After deparaffinizing in xylene and rehydrating through an ethanol series to fish saline (Murray et al. 2003), sections were equilibrated in $0 \cdot 1 \mathrm{M}$ triethanolamine (TEA, $\mathrm{pH} 7 \cdot 5$ ) for $5 \mathrm{~min}$ at room temperature with agitation and then acetylated in two further washes of fresh TEA containing $0 \cdot 025 \%(\mathrm{v} / \mathrm{v})$ acetic anhydride for an additional $5 \mathrm{~min}$ with vigorous agitation. The reaction was stopped in $2 \times \mathrm{SSC}$ for $2 \mathrm{~min}$ and sections were subsequently dehydrated through ethanol series, air-dried, and stored in an RNase-free container.

The ISH protocol, including prehybridization, riboprobe hybridization, and signal detection, was carried out using a Freedom EVO liquid handling robot (Tecan, San Jose, CA, USA). Slide assembly into Teflow chambers (Tecan) and instrument setup were as described in Yaylaoglu et al. (2005). The instrument was directed by a program script written using Gemini software (Tecan) and paralleled the manual ISH protocol as described in Murray et al. (2003). All liquid transfers and incubations took place on the automated platform. Briefly, sections were equilibrated in methanol, washed in fish saline and treated with proteinase $\mathrm{K}(2.5 \mu \mathrm{l} / \mathrm{ml})$ for $30 \mathrm{~min}$ at $37^{\circ} \mathrm{C}$. Sections were prehybridized in hybridization buffer for $30 \mathrm{~min}$ at $25^{\circ} \mathrm{C}$ and then hybridized at $47^{\circ} \mathrm{C}$ with two consecutive applications of probe (antisense $400 \mathrm{ng} / \mathrm{ml}$, and sense $200 \mathrm{ng} / \mathrm{ml}) \sim 2.5 \mathrm{~h}$ apart. Total hybridization time was $5 \mathrm{~h}$. After hybridization, sections were incubated in $50 \%(\mathrm{v} / \mathrm{v})$ formamide with $2 \times$ SSC and then washed $30 \mathrm{~min}$ in each of $2 \times \mathrm{SSC}, 0.5 \times \mathrm{SSC}$, and 
$0 \cdot 1 \times$ SSC at $47^{\circ} \mathrm{C}$. Following a blocking step in antibody buffer $(0 \cdot 1 \mathrm{M}$ Tris-HCl, $\mathrm{pH} 7 \cdot 5,150 \mathrm{mM} \mathrm{NaCl})$ with $1 \%$ $(\mathrm{w} / \mathrm{v})$ BSA and $10 \%(\mathrm{v} / \mathrm{v})$ goat serum, the hybridization signal was detected by incubating the sections for $30 \mathrm{~min}$ at $2{ }^{\circ} \mathrm{C}$ with a sheep anti-digoxigenin-alkaline phosphatase conjugate (Roche). The reaction was visualized by incubating for $15 \mathrm{~min}$ in a chromogenic buffer $(0 \cdot 1 \mathrm{M}$ Tris- $\mathrm{HCl} \mathrm{pH} \mathrm{9.5,}$ $0 \cdot 1 \mathrm{M} \mathrm{NaCl}, 0.05 \mathrm{M} \mathrm{MgCl}_{2}, 0 \cdot 1 \%$ (v/v) Tween 20, and $1 \mathrm{mM}$ levamisol) followed by $20 \mathrm{~min}$ incubation in fresh buffer containing $3 \cdot 5 \mu \mathrm{l} / \mathrm{ml}$ 5-bromo-4-chloro-3-indolylphosphate (Roche) and $4.5 \mu \mathrm{l} / \mathrm{ml}$ nitro blue tetrazolium (Roche). The reaction was stopped by washing in system water from the instrument and the reaction product stabilized by fixing in $4 \%(\mathrm{v} / \mathrm{v})$ paraformaldehyde in fish saline for $10 \mathrm{~min}$ followed by a final system water wash. Hybridization chambers were disassembled in clean water, the slides airdried at room temperature, mounted in an aqueous mounting media (Hydro-Matrix, Micro-Tech-Lab, Graz, Austria), and cover slipped for observation using a Leica DMRE microscope and image capture with an Orca camera system (Hamamatosu Inc., Bridgewater, NJ, USA) and Simple PCI software (Compix Inc. Imaging Systems, Cranberry Township, PA, USA). Image plates were created using Adobe Photoshop 6.0.1. (Adobe System Incorporated).

\section{Quantitative real-time PCR assays for gene expression in ontogenetic studies}

First-strand cDNA synthesis for each RNA extract was conducted using $2 \mu \mathrm{g}$ DNase I-treated total RNA and an oligo-dT primer with the RetroScript kit (Ambion). Amplification of cDNA was performed using an iCycler (Bio-Rad Laboratories). Data obtained for ghrelin were compared with data obtained from amplification of two reference genes, elongation factor $1-\alpha(\mathrm{EF} 1 \alpha)$ and $40 \mathrm{~S}$ ribosomal protein S4 (40S). Samples of cDNA were diluted 50-fold for use in the reference gene assays, while those for ghrelin were diluted either 10-fold or were used undiluted (pooled larval extracts). PCR $(20 \mu \mathrm{l})$ contained $2 \mu \mathrm{l}$ cDNA solution, $0 \cdot 8 \mu \mathrm{l}(10 \mu \mathrm{M})$ forward and reverse primers (Table 4),

Table 4 Primers used to perform quantitative PCR for determination of gene expression in larval and juvenile tissue samples

\section{Primer sequence}

Primer

Ghrelin forward

Ghrelin reverse

$\mathrm{EF} 1 \alpha-\mathrm{F}$

EF1 $\alpha-R$

40S-F

40S-R

RPL13a-F

RPL13a-R
5'-CTG ACC TTG TGG TGC AAG TCG-3'

5'-GGT AAA TCT GCC AAT CTT GTC C-3'

5'-AAG AGG ACC ATC GAG AAG TT-3'

5'-GTC TCA AAC TTC CAC AGA GC-3'

$5^{\prime}$-GCC AAG TAC AAG CTG TGC AA- $3^{\prime}$

5'-AGG TCG ATC TTG ACG GTG TC-3'

5'-CGG TTC AAT AAG GTT CTG CT-3'

5'-CAT CTC ACA ACC ACC ACT TT-3'
$\boldsymbol{T}_{\mathbf{m}}\left({ }^{\circ} \mathrm{C}\right)$

$58 \cdot 0$

$58 \cdot 0$
$6.4 \mu \mathrm{l}$ nuclease-free water, and $10 \mu \mathrm{l}$ iQ SYBR Green Supermix (Bio-Rad). PCR product sizes for ghrelin, EF1 $\alpha$, and $40 \mathrm{~S}$ were $305 \mathrm{bp}, 141 \mathrm{bp}$, and $138 \mathrm{bp}$ respectively. All reactions were performed in duplicate within a PCR assay and under the same cycling conditions: $95^{\circ} \mathrm{C}$ for $10 \mathrm{~min}$; 42 cycles of $95^{\circ} \mathrm{C}$ for $30 \mathrm{~s} ; 57^{\circ} \mathrm{C}$ for $30 \mathrm{~s}$; and $72{ }^{\circ} \mathrm{C}$ for $1 \mathrm{~min}$. Fluorescent data for quantification were collected at $82^{\circ} \mathrm{C}$. Melt curve analysis was performed over a range of $55-95^{\circ} \mathrm{C}$ in order to verify single product generation at the end of the assay.

The standard curve quantification method was used to analyze the data. Standard curves for ghrelin and reference genes were prepared from cloned PCR products inserted in pCR4-TOPO plasmids (Invitrogen). Standard curves were made from a 10-fold dilution series of linearized plasmid ranging from $10^{-1}$ to $10^{-8} \mathrm{ng}$ DNA. Analysis of the standard curves was performed by iCycler iQ Optical System Software (version 3.0a, Bio-Rad). Standards curves were frequently generated on data obtained from standards $10^{-2}$ to $10^{-7} \mathrm{ng}$ DNA. Data for all genes were converted to copy number (g DNA $\times 6 \cdot 022 \times 10^{23}$ copies per mole/(molecular mass of vector with product insert $\mathrm{g}$ per mole)). Ghrelin data were then normalized with the geometric mean of the copy numbers determined for the two reference genes.

RT-PCR and quantitative real-time PCR assays of tissuespecific ghrelin expression in 3-year-old halibut

First-strand cDNA synthesis was performed on $5 \mu \mathrm{g}$ DNase-treated total RNA using oligo-dT with SuperScript II RNase H- reverse transcriptase (Invitrogen) according to the protocol detailed in Matsuoka et al. (2006). The RT-PCR amplification of ghrelin cDNA was carried out as follows: denaturation at $95^{\circ} \mathrm{C}$ for $3 \mathrm{~min} ; 31$ cycles of denaturation at $95^{\circ} \mathrm{C}$ for $30 \mathrm{~s}$, annealing at $57^{\circ} \mathrm{C}$ for $30 \mathrm{~s}$, and extension at $72{ }^{\circ} \mathrm{C}$ for $30 \mathrm{~s}$; and a final extension step at $72{ }^{\circ} \mathrm{C}$ for $5 \mathrm{~min}$. Primers used for ghrelin amplification were the same as those used for quantitative PCR (Table 4). Amplification of glyceraldehyde 3-phosphate dehydrogenase (GAPDH) was performed on the cDNA samples using the same protocol but with an annealing temperature of $53^{\circ} \mathrm{C}$ (GAPDH forward primer, $5^{\prime}$-GTG TCA GTG GTT GAC CTG A-3'; GAPDH reverse primer, 5'-AGC TTG ACA AAG TGG TCA TT-3'). PCR amplicons were visualized on a $2 \%(\mathrm{w} / \mathrm{v})$ agarose gel with SYBR Safe DNA Gel Stain (Invitrogen).

Quantitative PCR was additionally performed on the tissue cDNA samples using the same protocol as outlined for the larval ontogenetic studies, with the exception that EF1 $\alpha$ and another reference gene, ribosomal protein L13A (RPL13A), were used as reference genes for normalization of tissue expression.

\section{Statistical analysis of expression data}

Normalized expression values obtained for different samples were averaged and the mean values were used for graphical 
representation along with their associated S.D. Kruskal-Wallis tests were performed to determine differences in normalized preproghrelin expression in developmental stage comparisons. The Wilcoxon two-sample test was used for post hoc comparisons. Statistical analysis was done using SYSTAT Version 11 (Systat Software Inc., San José, CA, USA).

\section{Results}

\section{Cloning of halibut preproghrelin $\mathrm{cDN} A$}

The initial PCR to isolate preproghrelin gene using degenerate primer P1 amplified three products, a prominent band of $\sim 800 \mathrm{bp}$ and two weaker bands of $\sim 640$ and $\sim 200 \mathrm{bp}$. The $800 \mathrm{bp}$ band was excised and identified as preproghrelin. The smaller weaker bands were therefore not studied further. Following $5^{\prime}$ RACE and further cloning and sequencing, the full 899 bp cDNA sequence was obtained for halibut. The sequence includes a $5^{\prime}$-untranslated region of $51 \mathrm{bp}$, an open reading frame of $315 \mathrm{bp}$ that encodes an 105 amino acid preproghrelin, and a $3^{\prime}$-untranslated region of 533 bp (Fig. 1). For the latter, two potential polyadenylation signals (aataa) were seen, one at position 882-887 near the end of the cloned sequence and another well upstream of the poly-A tail at position 619-624.
The amino acid sequence deduced from halibut preproghrelin cDNA showed the highest amino acid identity with sequences from perciform teleosts (69-67\% identity with black sea bream, sea bass, and both tilapia species; Fig. 2). Intermediate identity was seen with the two rainbow trout sequences (47 and 50\% identity for rainbow trout preproghrelin sequences 1 and 2 respectively). Lower identity values occurred with sequences obtained from the Japanese eel (41\%) and the ostariophysan teleosts, i.e., goldfish (38\%), zebrafish (38\%), catfish (33\%). The first 12 amino acids of the mature ghrelin peptide in teleosts are highly conserved. This area of the sequence is identical among the four perciforms and rainbow trout; however, the deduced sequence for halibut shows two departures to this trend with novel substitutions at amino acids 9 and 12 of the mature ghrelin sequence. Other substitutions are evident for ostariophysan teleosts at positions 2 and 8, and for Japanese eel, a different residue is present only at position 10 . The deduced sequence for mature halibut ghrelin reveals that the putative peptide is 19 amino acids in length with a potential amidation signal at the C-terminus; GSSFLSPSHKPPKGKPPRA-amide.

A sequence was found within halibut and other teleostean preproghrelins that aligned with the 23 amino acid sequence of human obestatin (Fig. 2). These aligned areas in fish preproghrelins show low identity with human obestatin. However, there appears to be substantial conservation within the teleosts. Basic amino acids (Lys and Arg) typical of

Figure 1 Nucleotide and deduced amino acid sequence of halibut preproghrelin cDNA. The nucleotide sequence for halibut ghrelin is accessible through GenBank (accession number EF493849). Areas of the sequence corresponding to primers used for the initial PCR, $5^{\prime}$ RACE, q-PCR, and cloning of the full sequence are indicated by underlining or shading and are labeled as in Table 1 . Potential polyadenylation signals (aataaa) are indicated by bold text. 

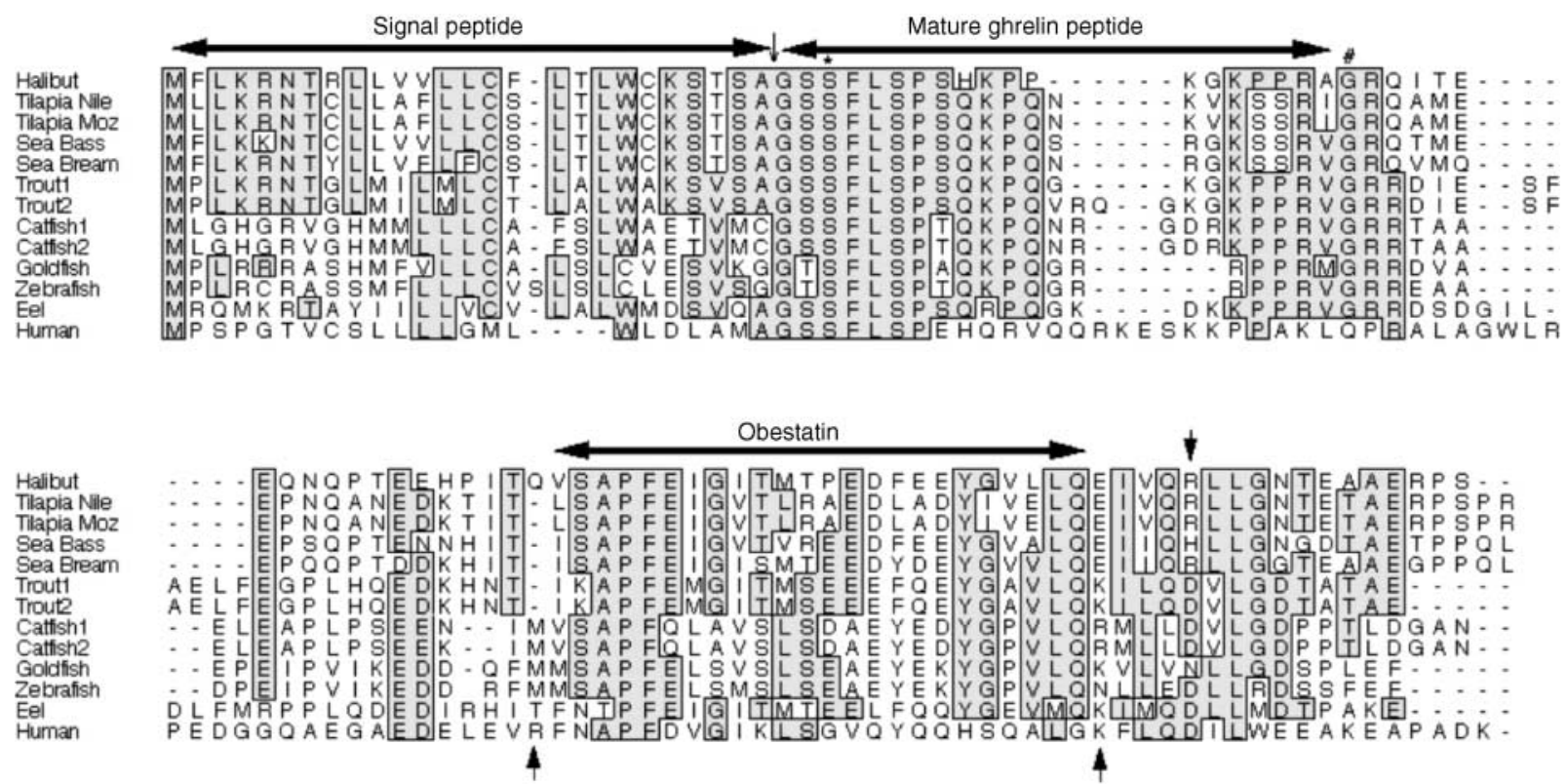

Figure 2 Amino acid alignment of the sequence deduced from halibut preproghrelin cDNA with sequences available in GenBank for other teleosts and for humans. Accession numbers: Japanese eel, AB062427; goldfish, AF454390; zebrafish, AM055940; channel catfish1, AB196450; channel catfish2, AB196449; rainbow trout 1, AB096919; rainbow trout 2, AB101443; black sea bream, AY643809; sea bass, DQ665912; Nile tilapia, AB104860; Mozambique tilapia, AB077764; Atlantic halibut, EF493849; human, AB035700). *Indicates the third serine residue representing the bioactive core of the mature ghrelin peptide. ${ }^{\#}$ Indicates the amidation signal for teleostean ghrelin peptides. Areas of the preproghrelin peptide that align with the human obestatin sequence are indicated. Putative convertase sites represented by basic amino acids ( $\mathrm{K}$ and $\mathrm{R}$ ) are shown by arrows.

putative convertase cleavage sites are reported to flank the human obestatin sequence (Fig. 2). No equivalent site is seen on the amino terminus of the peptide sequence in teleosts, but six of the seven non-acanthopterygian teleosts show a convertase site at the carboxy terminus that aligns with the site on the human sequence. Halibut and most perciforms have an Arg residue that is four amino acids downstream from this position.

\section{Ontogenetic ghrelin expression in larval halibut}

Quantitative PCR analysis on three replicate sets of pooled larvae collected at five different developmental stages demonstrated that the ghrelin gene is expressed as early as hatching (Fig. 3). Low levels of ghrelin expression were seen over the yolk-sac stage (S1 and S2) with little change in normalized expression occurring even by prometamorphosis (S6 post-notochord flexion). Increased expression was associated with metamorphosis (S7 to S9). The highest expression level was seen for fish staged as either juveniles or advanced climax metamorphic stage 9 larvae. Changes in normalized ghrelin expression over larval development were statistically significant over time $(P<0 \cdot 05$, Fig. 3$)$

In order to confirm the results demonstrated by pooled larval samples, individuals were examined at the point when ghrelin levels were seen to increase from prometamorphosis to early climax metamorphosis (developmental stages 7-9).
Five individual larvae from each of three stages spanning this developmental progression were examined for visceral ghrelin expression. Levels in mean individual normalized expression were similar to the data obtained from pooled larval samples

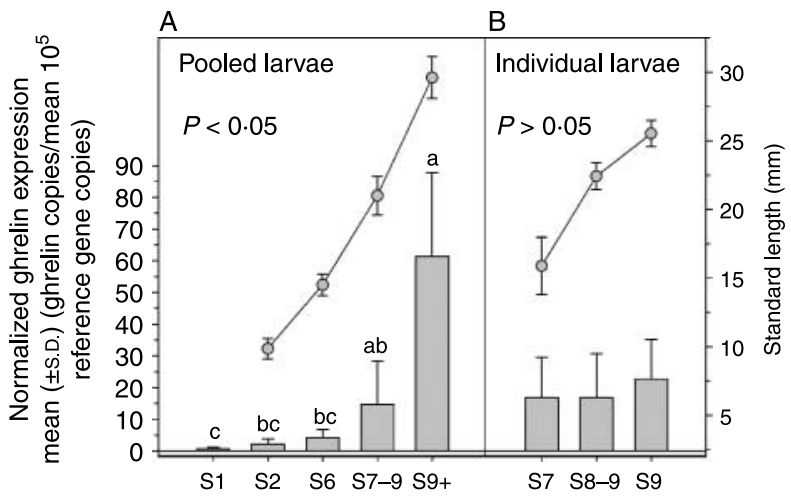

Figure 3 Normalized expression patterns of preproghrelin mRNA and growth curves in halibut larvae. (A) Mean ( \pm s.D.) normalized expression for larvae sampled from hatching to late metamorphosis/juvenile stages (S1-S9+; RNA from pooled larvae). (B) Mean $( \pm$ s.D.) normalized expression patterns of preproghrelin mRNA in individual halibut larvae sampled during metamorphosis $(n=5$ individuals per group). Ghrelin copy number data were normalized by the geometric mean of copy number data from two reference genes (EF1 $\alpha$ and $40 S$ ). Curves for growth in length (mean \pm s.D.) are shown for both experiments. Means indicated by the same letter are not significantly different $(P>0 \cdot 05)$. 
during the S7-S9 period. No statistically significant increase in mean normalized expression was seen over the three developmental groupings as individual variability was high within each stage (Fig. 3).

\section{Cellular localization of ghrelin by ISH}

In terms of methodology, the present study is the first to employ an automated liquid handling platform to perform ISH on fish tissues. In contrast to the method described in Yaylaoglu et al. (2005), the process here does not utilize an amplification step. The procedure is directly adapted from a previously published manual protocol (Murray et al. 2003) and seems to be effective in detecting moderately expressed genes such as halibut ghrelin. The expression signal was very specific to cell type and showed no significant background.

Halibut of varying size and developmental stage (larval stage 7 to post-metamorphic juvenile) were examined for the presence and distribution of ghrelin-expressing cells. The greatest number of cells was observed in stage 9 to postmetamorphic fish; no difference in cell number or distribution was noted across the size range of fish sampled among these stages. Although all tissues of the fish were examined, ghrelin-expressing cells were only observed in the stomach mucosa (Fig. 4A). Some of these cells were triangular or pyramidal in shape and showed a distinct luminal orientation with a basal nucleus, but they were never observed to reach the luminal surface (Fig. 4B). Other ghrelin-expressing cells were more rounded in shape and did not appear to have a luminal orientation. A strong signal was evident throughout the cytoplasm of ghrelin-expressing cells. No signal was observed for tissues hybridized with a sense probe (Fig. 4C).

\section{Tissue distribution analysis of ghrelin expression in 3-year-old immature halibut}

Assessment of ghrelin expression by RT-PCR showed that among the tissues sampled from six halibut (three males and three females), the strongest expression was seen for stomach tissue (Fig. 5). Expression was also evident for most individuals in the following tissues after 31 cycles of amplification: pyloric caecae ( $n=6$ fishes), intestine $(n=5)$, and both the ovaries $(n=2-3)$ and testes $(n=3)$. Examining RT-PCR data obtained after an additional two cycles of amplification suggested that ghrelin was either weakly expressed or absent in other tissues. Tissues with low-level expression include the brain $(n=3$ fishes), gills $(n=3)$, heart $(n=1)$, and kidney $(n=2)$. Individuals with expression in the brain demonstrated general weak- to low-level expression among the different regions of the brain. RT-PCR did not show prominent expression in any one region that was consistent among individuals.

In order to clarify the major sites of ghrelin expression, quantitative PCR was performed on the same RNA samples. The data confirmed that detectable levels of ghrelin mRNA were seen mainly for those tissues that demonstrated good signals in RT-PCR, namely, the digestive and gonadal tissues
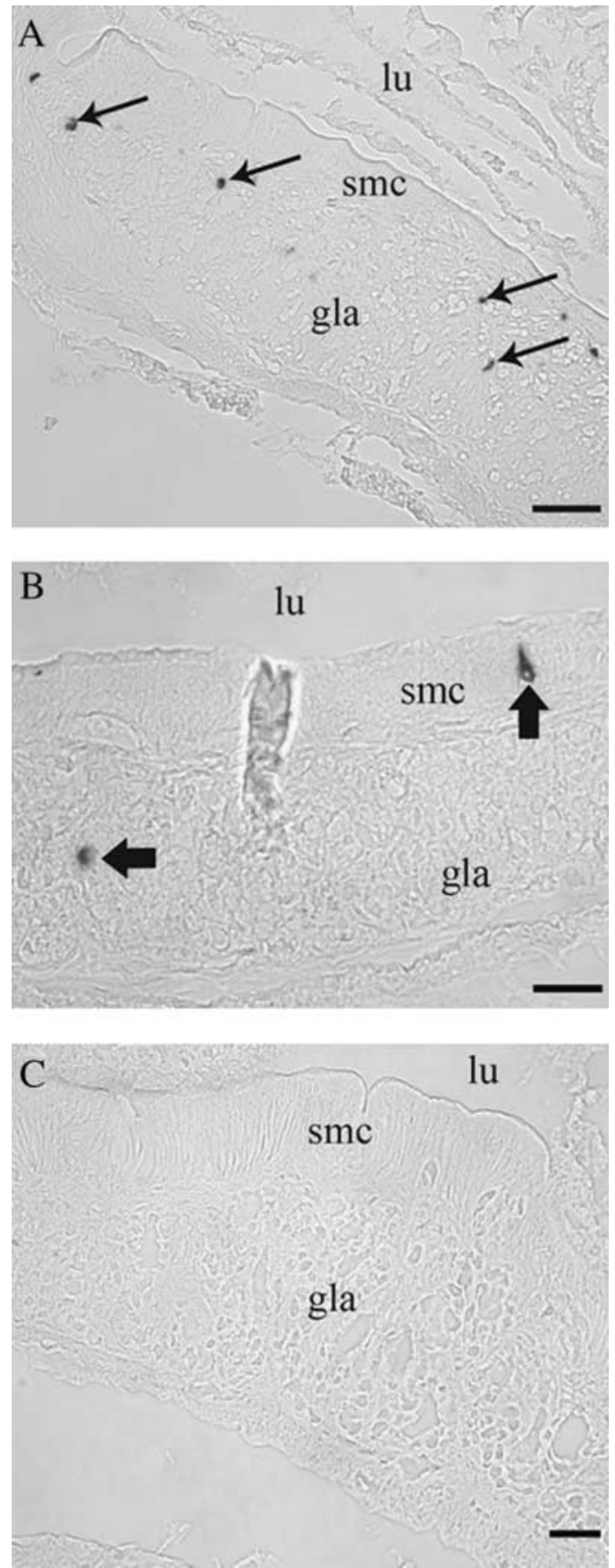

Figure 4 Cardiac region of the stomach from a post-metamorphic halibut following in situ hybridization with a riboprobe for halibut ghrelin. (A) Overview of glandular region giving the distribution of cells showing positive for ghrelin mRNA (arrows). Bar $=50 \mu \mathrm{m}$.

(B) High-resolution image of the gastric mucosa showing individual ghrelin-expressing cells in both the surface mucous cell (smc) layer and the glandular layer (gla; black arrows). Note the triangular shape and orientation of cell in the surface mucous cell layer and the round shape of the cells in the glandular layer. Bar $=20 \mu \mathrm{m}$.

(C) Gastric region following hybridization with a control sense probe for ghrelin. Bar $=20 \mu \mathrm{m}$. lu=lumen. 


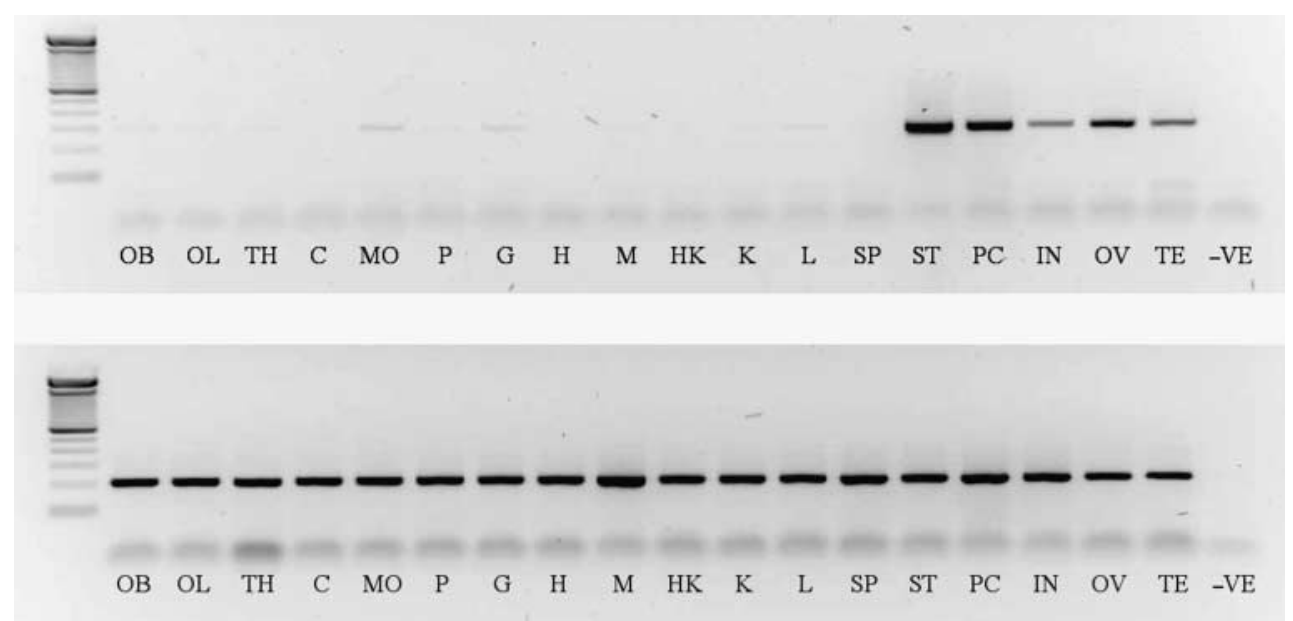

Figure 5 RT-PCR identification of preproghrelin expression in different tissues of 3-year-old halibut. Data shown are from one representative halibut, with the exception of gonadal expression. Preproghrelin transcripts were amplified by 31 cycles (top row). A GAPDH expression was performed as a control RT-PCR for the confirmation of cDNA quality (bottom row). Lanes: 100 bp marker; olfactory bulb, OB; optic lobe, $\mathrm{OL}$; thalamus and hypothalamus, $\mathrm{TH}$; cerebellum, C; medulla oblongata, MO; pituitary, P; gill, G; heart, H; muscle, M; head kidney, HK; kidney, K; liver, L; spleen, SP; stomach, ST; pyloric caecae, PC; intestine, IN; ovary, OV; testis, TE; negative control, -VE.

(Fig. 6). Additional tissues with levels above the threshold for detection included gill tissue from one female, and medullar tissue from the brains of the three males. Medullar expression was the only sex-related difference in ghrelin expression that could be observed in 3-year-old halibut. Ghrelin expression indicated in other tissues samples by RT-PCR was not confirmed by quantitative PCR.

\section{Discussion}

The preproghrelin cDNA sequence isolated from Atlantic halibut was within the range of those reported for perciforms

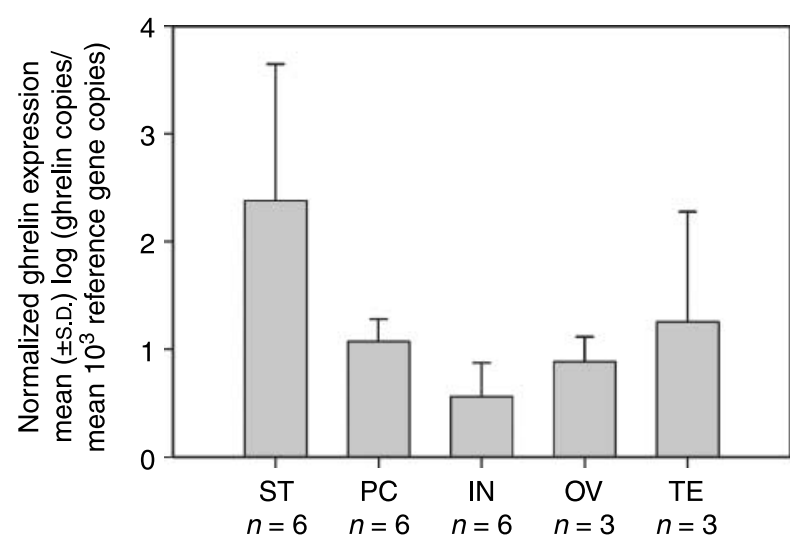

Figure 6 Quantitative real-time PCR analysis of preproghrelin expression in tissues of 3 -year-old halibut showing mean ( \pm s.D.) $\log _{10}$ normalized expression. Ghrelin copy number data were normalized by the geometric mean of copy number data $\left(\times 10^{3}\right)$ from two reference genes (EF1 $\alpha$ and RPL13a). Tissues with detectable levels of ghrelin transcripts are shown: stomach, ST; pyloric caecae, PC; intestine IN; ovary, OV; testis, TE.
(798-941 bp). Teleosts representing older evolutionary lines have shorter transcripts $\sim 500 \mathrm{bp}(<535 \mathrm{bp})$. The detection of two putative poly-adenylation signals within the cloned sequence for halibut suggests the presence of an additional smaller transcript. Multiple transcripts of varying stability can be expressed, and more than one ghrelin transcript has been found in channel catfish, rainbow trout, mouse, and human (Kaiya et al. 2003b, 2005, Gualillo et al. 2006). Although the cloned sequence was the most prominent band found in initial isolation PCR, the weaker $640 \mathrm{bp}$ band detected could represent an alternate transcript associated with the second poly-adenylation signal.

Halibut preproghrelin had the highest amino acid identity with preproghrelin sequences from other acanthopterygian teleosts represented by the four perciform species (i.e., tilapias, sea bass, and black sea bream). The deduced 105 amino acid preproghrelin sequence is within the range seen in other fishes (103-111 aa). The active core of the mature ghrelin peptide, represented by the first four amino acids (GSSF), is conserved in all vertebrates studied thus far with the exception of goldfish (Unniappan et al. 2002), zebrafish, and the bullfrog Rana catesbeiana (Kaiya et al. 2001). Generally, the first seven amino acids of the mature peptide are highly conserved among the vertebrates, but if one examines the teleosts alone the conserved area increases to the first 12 amino acids.

A conserved region that aligns with human obestatin was seen within halibut preproghrelin, similar to the previously reported sea bream sequence (Yeung et al. 2006). Mammalian obestatin has been reported to be anorexigenic (Zhang et al. 2005, Lagaud et al. 2007). However, effects on appetite suppression in normal or ghrelin-stimulated animals remain controversial (Seoane et al. 2006, Gourcerol \& Taché 2007). Whether obestatin is translated in fishes and forms a functional peptide is unknown. Convertase cleavage sites (represented by the basic amino acids Arg or Lys) 
that flank mammalian obestatin are not seen at the amino termini of the teleost sequences, but a number of species may have sites at the carboxy termini of their sequences. In addition, the carboxy terminus of the mammalian obestatin sequence is flanked by a glycine residue indicating amidation, which is important for obestatin bioactivity (Zhang et al. 2005). This is not observed in the putative obestatin sequences of teleosts, but is seen among their functional ghrelin peptides. The potential role of obestatin in fishes requires further investigation.

The examination of ghrelin expression through halibut larval development revealed that ghrelin transcripts were detectable from hatching. This is the first report of ghrelin gene expression during teleostean larval development. The biological significance of ghrelin expression during the yolk-sac stage is unclear as growth and nutrition at this time are based on the endogenous energy supplies of the yolk. A role in embryonic development, rather than appetite, may be more relevant for ghrelin at hatching. Studies in mammals that support this idea include reports of ghrelin expression in early embryo development (morula cells, Kawamura et al. 2003) and ghrelin-mediated induction of fetal neurogenesis (Sato et al. 2006).

Normalized ghrelin expression changed little between hatching, mouth-opening, and prometamorphosis (stage 6). Notable increases in expression were seen in larvae undergoing metamorphosis, particularly the later stages of climax metamorphosis and entry into the post-metamorphic juvenile stage $(\mathrm{S} 9+)$. Metamorphosis is a period when anatomical relationships and physiological systems mature. This is evident in the endocrine systems as well. For instance Einarsdóttir et al. (2006) reported that the pituitary completes development by stage 7 and an increase in pituitary endocrine cells is seen with climax metamorphosis. In terms of ghrelin, increases in expression during advanced metamorphosis are likely tied to the concurrent changes in stomach development. The glandular area of the stomach develops from first feeding in halibut larvae (66 dph; Murray et al. 2006). Initial gastric gland formation was confirmed histologically for stage 6 larvae of the present study (data not shown). Organized glandular areas were detected in metamorphic stages 7-9, but separate mucosal and glandular layers of the stomach were not detected until late climax metamorphosis and post-metamorphosis. These results are consistent with patterns detailed in Murray et al. (2006), which indicate that stomach development, glandular/mucosal layer differentiation, and gastric functionality, shown by pepsinogen expression, are closely associated with metamorphosis. The differentiation of the stomach layers may influence the increase in ghrelin expression since ghrelin-expressing cells were detected in both glandular and mucosal layers of the stomach in halibut larvae.

Two morphological types of ghrelin-expressing cells were evident in the halibut stomach. These were similar to the openand closed-type cells described in the gastric region of rainbow trout (Sakata et al. 2004). The triangular-shaped cells seen in the surface mucosal layer of the halibut stomach may represent opentype cells as they had a definite luminal orientation. In contrast, other ghrelin-positive cells noted in the glandular region of the stomach, but lacking any discernable orientation, appear to be closed-type cells. These observations are supported by Murray et al. (1994) in an ultrastructural study that described two enteroendocrine cells from the halibut stomach, one of which was seen to have a distinct luminal orientation. Mammalian ghrelin-positive cells (enteroendocrine X/A-like cells, Date et al. 2000) are only seen as the closed-type variety in human and rat stomachs, but are found as both open- and closed-type cells in the lower gastrointestinal tract of rat (Sakata et al. 2002).

Although ghrelin expression in 3-year-old halibut was strongest in stomach, significant expression was also detected in other digestive tissues and in the gonads using sensitive PCR assays. In contrast, ISH results for stage 9 larvae and post-metamorphic juveniles revealed discernable transcripts only in the stomach, despite numerous attempts to detect expression with serial sections of cranial and abdominal regions. This discrepancy suggests that the sensitivity of the ISH method was insufficient for detection of ghrelin expressed in other post-metamorphic tissues than stomach. Alternatively, ghrelin-producing cells may become more numerous in non-gastric tissue with further maturation of the digestive system and can only be detected by ISH in older fish.

Ghrelin expression in fishes is variously reported to be confined to the stomach (Nile tilapia, Parhar et al. 2003; sea bream, Yeung et al. 2006) or to be more widely distributed. In mammals, ghrelin-producing cells, although concentrated in the stomach, are distributed along the digestive tract and have also been detected in human insulin-secreting $\beta$-cells of the pancreas (Volante et al. 2002). Goldfish, which lack a distinct stomach, express ghrelin mainly in the intestine (Unniappan et al. 2002). Intestinal expression was also identified by RT-PCR in rainbow trout and Japanese eel (Kaiya et al. 2003a,b). Lowlevel ghrelin expression in pyloric caecae has been reported in rainbow trout (Kaiya et al. 2003b). For halibut, expression in the pyloric caecae may originate from the diffuse pancreas associated with these digestive structures (Murray et al. 2006). Pancreatic expression has been noted in channel catfish (Kaiya et al. 2005).

Only weak ghrelin expression was observed in the halibut brain, which agrees with the general pattern reported for other teleosts (Unniappan \& Peter 2005). Ghrelin expression in the brain has been observed in Japanese eel (Kaiya et al. 2003a), rainbow trout (Kaiya et al. 2003b), Mozambique tilapia (Kaiya et al. 2003c), and goldfish (Unniappan et al. 2002). Studies for rainbow trout and goldfish have demonstrated ghrelin expression in the telencephalon and hypothalamus, with hypothalamic expression having been originally observed in the rat brain (Kojima et al. 1999). Despite the evidence of hypothalamic ghrelin expression in two other teleosts, our analyses using quantitative PCR could only confirm ghrelin expression in the medulla oblongata of male 3-year-old halibut. Expression levels in other areas of the brain, including the thalamus and hypothalamus, were only at the threshold of detection.

Halibut is the first species for which gonadal ghrelin expression has been found among teleosts. Only two other studies have examined fish gonads for ghrelin expression, but no expression was detected (Unniappan et al. 2002, Parhar et al. 2003). Mammalian studies suggest autocrine/paracrine roles for 
ghrelin in both the ovary and the testis. Ghrelin expression has been shown in steroidogenic and other somatic cells of the mammalian gonads, while expression of its receptor (GHS-R1a) has been noted in both the somatic and germ cells (Barreiro \& Tena-Sempere 2004). Thus, the detection of gonadal ghrelin production in halibut prompts the question as to whether this peptide might have a regulatory role in fish reproduction.

In conclusion, we have cloned preproghrelin from Atlantic halibut, the first pleuronectiform teleost to be examined in terms of ghrelin expression. Similarities in mRNA transcript length and amino acid sequence reflect the evolutionary links between halibut and other acanthopterygian teleosts. This study is the first to examine ghrelin expression during fish larval development. The data indicate low levels of ghrelin expression during the prolonged yolk-sac larval stage, prior to exogenous feeding and the differentiation of the stomach. This suggests that ghrelin has activities beyond appetite stimulation and $\mathrm{GH}$ secretion in early stages. It may also indicate expression in nongastric tissues, or a role in development, as has been shown in mammals. Increased expression during larval development was clearly associated with climax metamorphosis and the differentiation of the stomach. ISH showed that dominant expression occurs in stomach tissue. Expression is localized within two cell types associated with the luminal and gastric areas of the developing stomach. The examination of 3-year-old halibut demonstrated that ghrelin is expressed in other tissues including intestine, pyloric caecae, and the immature gonads. Ghrelin effects on appetite and $\mathrm{GH}$ release in vertebrates suggest that this hormone could be physiologically important both during and after the larval stage of fishes.

\section{Acknowledgements}

We would like to thank Scotian Halibut Limited, for providing larval samples for the study, and Dr Stewart Johnson for his review of the manuscript. Our appreciation is also extended to Dr Leah Knickle for her assistance with larval RNA extraction. This is NRCC publication number 42707. Funding for this project was provided by the National Research Council of Canada. The authors declare that there is no conflict of interest that would prejudice the impartiality of this study.

\section{References}

Barreiro ML \& Tena-Sempere M 2004 Ghrelin and reproduction: a novel signal linking energy status and fertility? Molecular and Cellular Endocrinology $2261-9$.

Broglio F, Gottero C, Prodam F, Gauna C, Muccioli G, Papotti M, Abribat T, van der Lely AJ \& Ghigo E 2004 Non-acylated ghrelin counteracts the metabolic but not the neuroendocrine response to acylated ghrelin in humans. Journal of Clinical Endocrinology and Metabolism 89 3062-3065.

Date Y, Kojima M, Hosoda H, Sawaguchi A, Mondal MS, Suganuma T, Matsukura S, Kangawa K \& Nakazato M 2000 Ghrelin, a novel growth hormone-releasing acylated peptide, is synthesized in a distinct endocrine cell type in the gastrointestinal tracts of rats and humans. Endocrinology 141 4255-4261.
Einarsdóttir IE, Silva N, Power DM, Smáradóttir H \& Björnsson BT 2006 Thyroid and pituitary gland development from hatching through metamorphosis of a teleost flatfish, the Atlantic halibut. Anatomica Embryologica 211 47-60.

Gourcerol G \& Taché Y 2007 Obestatin - a ghrelin-associated peptide that does not hold its promise to suppress food intake and motility. Neurogastroenterology and Motility 19 161-165.

Gualillo O, Lago F, Casanueva FF \& Diguez C 2006 One ancestor, several peptides post-translational modifications of preproghrelin generate several peptides with antithetical effects. Molecular and Cellular Endocrinology 256 1-8.

Kaiya H, Kojima M, Hosoda H, Koda A, Yamamoto K, Kitajima Y, Matsumoto M, Minamitake Y, Kikuyama S \& Kangawa K 2001 Bullfrog ghrelin is modified by an $n$-octanoic at its third threonine residue. Journal of Biological Chemistry 276 40441-40448.

Kaiya H, Kojima M, Hosoda H, Riley LG, Hirano T, Grau EG \& Kangawa K 2003a Amidated fish ghrelin: purification, cDNA cloning in the Japanese eel and its biological activity. Journal of Endocrinology 176 415-423.

Kaiya H, Kojima M, Hosoda H, Moriyama S, Takahashi A, Kawauchi H \& Kangawa K 2003 beptide purification, complementary deoxyribonucleic acid (DNA) and genomic DNA cloning, and functional characterization of ghrelin in rainbow trout. Endocrinology 144 5215-5226.

Kaiya H, Kojima M, Hosoda H, Riley LG, Hirano T, Grau EG \& Kangawa K $2003 c$ Identification of tilapia ghrelin and its effects on growth hormone and prolactin release in the tilapia, Oreochromis mossambicus. Comparative Biochemistry and Physiology, Part B 135 421-429.

Kaiya H, Small BC, Bilodeau AL, Shepherd BS, Kojima M, Hosoda H \& Kangawa K 2005 Purification, cDNA cloning and characterization of ghrelin in channel catfish, Ictalurus punctatus. General and Comparative Endocrinology 143 201-210.

Kawamura K, Sato N, Fukuda J, Kodama H, Kumagai J, Tanikawa H, Nakamura A, Honda Y, Sato T \& Tanaka T 2003 Ghrelin inhibits the development of mouse preimplantation embryos in vitro. Endocrinology 144 2623-2633.

Kojima M, Hosoda H, Date Y, Nakazato M, Matsuo H \& Kangawa K 1999 Ghrelin is a growth-hormone-releasing acylated peptide from stomach. Nature 402 656-660.

Lagaud GJ, Young A, Acena A, Morton MF, Barrett TD \& Shankley NP 2007 Obestatin reduces food intake and suppresses body weight gain in rodents. Biochemical and Biophysical Research Communications 357 264-269.

van der Lely A, Tschöp M, Heiman ML \& Ghigo E 2004 Biological, physiological, pathophysiological, and pharmacological aspects of ghrelin. Endocrine Reviews 25 426-457.

Matsuoka MP, van Nes S, Anderson O, Benfey TJ \& Reith M 2006 Real-time PCR analysis of ovary- and brain-type aromatase gene expression during Atlantic halibut (Hippoglossus hippoglossus) development. Comparative Biochemistry and Physiology, Part B 144 128-135.

Murray HM, Wright GM \& Goff GP 1994 A comparative histological and histochemical study of the stomach from three species of Pleuronectid, the Atlantic halibut Hippoglossus hippoglossus, the yellowtail flounder, Pleuronectes ferruginea, and the winter flounder, Pleuronectes americanus. Canadian Journal of Zoology 72 1199-1210.

Murray HM, Douglas SE, Gallant JW, Perez-Casanova JC \& Johnson SC 2003 Ontogeny of lipase expression in Winter Flounder, Pseudopleuronectes americanus. Journal of Fish Biology 62 816-833.

Murray HM, Gallant JW, Johnson SC \& Douglas SE 2006 Cloning and expression analysis of three digestive enzymes from Atlantic halibut (Hippoglossus hippoglossus) during early development: predicting gastrointestinal functionality. Aquaculture 252 394-408.

Parhar IS, Sato H \& Sakuma Y 2003 Ghrelin gene in cichlid fish is modulated by sex and development. Biochemical and Biophysical Research Communications 305 169-175.

Pittman K, Skiftesvik AB \& Berg L 1990 Morphological and behavioural development of halibut, Hippoglossus hippoglossus (L.) larvae. Journal of Fish Biology 37 455-472.

Ran X, Li W \& Lin H 2004 Rat ghrelin stimulates GH release and GH mRNA expression in the pituitary of orange-spotted grouper, Epinephelus coioides. Fish Physiology and Biochemistry 30 95-102. 
Riley LG, Fox BK, Kaiya H, Hirano T \& Grau EG 2005 Long-term treatment of ghrelin stimulates feeding, fat deposition, and alters the GH/IGF-I axis in the tilapia, Oreochromis mossambicus. General and Comparative Endocrinology 142 234-240.

Sæle Ø, Solbakken JS, Watanabe K, Hamre K, Power D \& Pittman K 2004 Staging of Atlantic halibut (Hippoglossus hippoglossus) from first-feeding through metamorphosis, including cranial ossification independent of eye migration. Aquaculture 239 445-465.

Sakata I, Nakahara K, Yamazaki M, Matsubara M, Hayashi Y, Kangawa K \& Sakai T 2002 Ghrelin-producing cells exist as two types of cells, closed- and opened-type cells, in the rat gastrointestinal tract. Peptides 23 531-536.

Sakata I, Mori T, Kaiya H, Yamazaki M, Kangawa K, Inoue K \& Sakai T 2004 Localization of ghrelin-producing cells in the stomach of the rainbow trout (Oncorhynchus mykiss). Zoological Science 21 757-762.

Sato M, Nakahara K, Goto S, Kaiya H, Miyazato M, Date Y, Nakazato M, Kangawa K \& Murakami N 2006 Effects of ghrelin and des-acyl ghrelin on neurogenesis of the rat fetal spinal cord. Biochemical and Biophysical Research Communications 350 598-603.

Seoane LM, Casanueva FF, Al-Massadi O \& Pazos Y 2006 Central obestatin administration does not modify either spontaneous or ghrelin-induced food intake in rats. Journal of Endocrinological Investigation 29 RC13-RC15.

Tossi A, Scocchi M, Zanetti M, Gennaro R, Storici P \& Romeo D 1997 An approach combining rapid cDNA amplification and chemical synthesis for the identification of novel, cathelicidin-derived, antimicrobial peptides. Methods in Molecular Biology 78 133-150.

Unniappan S \& Peter RE 2005 Structure, distribution and physiological functions of ghrelin in fish. Comparative Biochemistry and Physiology, Part A $140396-408$
Unniappan S, Lin X, Cervini L, Rivier J, Kaiya H, Kangawa K \& Peter RE 2002 Goldfish ghrelin: molecular characterization of the complementary deoxyribonucleic acid, partial gene structure and evidence for its stimulatory role in food intake. Endocrinology 143 4143-4146.

Unniappan S, Canosa LB \& Peter RE 2004 Orexigenic actions of ghrelin in goldfish: feeding-induced changes in brain and gut mRNA expression and serum levels, and responses to central and peripheral injections. Neuroendocrinology 79 100-108.

Volante M, Allì E, Gugliotta P, Funaro A, Broglio F, Deghenghi R, Muccioli G, Ghigo E \& Papotti M 2002 Expression of ghrelin and of the GH secreatgogue receptor by pancreatic islet cells and related endocrine tumors. Journal of Clinical Endocrinology 87 1300-1308.

Yaylaoglu MB, Titmus A, Visel A, Alvarez-Balado G, Thaller C \& Eichele G 2005 Comprehensive expression atlas of fibroblast growth factors and their receptors generated by a novel robotic in situ hybridization platform. Developmental Dynamics 234 371-386.

Yeung C-M, Chan C-B, Woo NYS \& Cheng CHK 2006 Seabream ghrelin: cDNA cloning, genomic organization and promoter studies. Journal of Endocrinology 189 365-379.

Zhang JV, Ren P-G, Avsian-Kretchmer O, Luo C-W, Rauch R, Klein C \& Hsueh AJW 2005 Obestatin, a peptide encoded by the ghrelin gene, opposes ghrelin's effects on food intake. Science 310 996-999.

\section{Received in final form 8 October 2007 \\ Accepted 17 October 2007 \\ Made available online as an Accepted Preprint 17 October 2007}

